\title{
Reflections
}

\section{The timely return of the repressed - commentary to Walton}

\author{
ANDY INCH
}

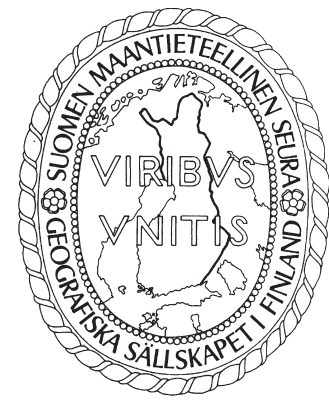

Inch, A. (2018) The timely return of the repressed - commentary to Walton. Fennia 196(1) 99-102. https://doi.org/10.11143/fennia.69822

This reflection discusses my response to William Walton's research paper in this issue of the journal. In it I explore how a timely invitation to take part in the open review process prompted thoughts about my ongoing involvement in the politics of planning in Scotland. Drawing on experience of campaigning for a fair and inclusive planning system, I briefly reflect on why the post-political has proven such an attractive theoretical lens for recent attempts to understand urban planning under neoliberalism. Suggesting that it seems to capture something important about ongoing attempts to reshape planning ideas and practices in Scotland, I go on to consider how Walton's paper brings to light important concerns about the loss of democratic accountability. Overall, I try to explore how the repression of energies required to sustain a post-political settlement may nonetheless provide a resource for acting in and against the dominance of market rationalities.

Keywords: planning, post-politics, democracy, public participation

Andy Inch, Instituto de Ciências Sociais, Universidade de Lisboa, Av. Prof. A. De Bettencourt, 9, Lisbon, 1600-189, Portugal. E-mail: andy.inch@ics.ulisboa.pt

It doesn't happen to me all that often but sometimes you can end up reviewing a paper for an academic journal that is relevant to more than just scholarly debates and concerns. As luck would have it, being part of the open review process for William Walton's (2018) paper in this issue of Fennia was such an occasion.

As I write this commentary I am on a train heading north towards Edinburgh. When I get there, I will be giving evidence to the Local Government and Communities Committee of the Scottish Parliament on behalf of a non-profit organisation called Planning Democracy (PD) I work with. PD campaigns for a fair and inclusive planning system in Scotland and over recent years have built up a network of supporters across the country'. Typically these are groups and individuals who have reached out for assistance, mostly in frustration, as they struggle to influence how places they care about are being changed.

The evidence session has been called because the Scottish Government (SG), currently led by a minority Scottish Nationalist Party administration, has drafted new planning legislation. Assuming this is passed in some form or other, it will be just the second time that Scotland has made use of its powers to legislate on planning matters since devolution in 1999. Walton's paper offers a timely, critical appraisal of some as yet under-examined consequences of changes introduced on the previous occasion in 2006.

The current draft planning bill emerged following more than two years of deliberation amongst "stakeholders" during which hundreds of groups have devoted thousands of hours to a succession 
of consultations, working groups, seminars, evidence sessions and the like. Many including PD have done so on an almost entirely voluntary basis. And, to be honest, at times we've questioned why we're bothering.

Throughout the process, there has been a strong suspicion that the SGs surprise decision to seek a 'root and branch' review of the planning system was driven by lobbying from the development sector, particularly the housebuilding industry. The housebuilders' view is that planning processes are little more than a bureaucratic burden, imposing costs and delay which prevent the market from efficiently "delivering", whether on quasi-magical promises of "growth" or the levels of new housing required to meet projected needs. This has become central to the ruling common-sense about planning in Scotland.

It is a hegemonic logic that constructs spatial planning as a problem rather than a positive means of realizing any publicly defined objectives for the use and development of land. In turn, this logic generates reforms whose primary purpose is to streamline planning processes, seeking to speed up decision-making and minimize regulation. Related problematizations of planning have, of course, become core to the repertoire of neoliberal spatial governance, performed with minor variations in many places in recent years. The "planning as a barrier" discourse has become an article of ideological faith to the extent that it can be reproduced with little regard to anything as considered as evidence. In response, the Lacanian planning theorist Michael Gunder (2016) suggests that the scapegoating of planning is playing a part in sustaining the powerful ideological fantasies that underpin neoliberal rule. The effect of this discourse is to discipline the role of planning to facilitation of the market-led development on which "growth" is seen to rely. Increasingly, sustaining land and property markets has become the key public good that policy-makers seek from planning. It is an approach that is broadly unquestioning of the nature and structure of those markets themselves, representing them as something like the weather whose vicissitudes need to be lived with but cannot be changed.

So far so familiar. Seen in these terms, it is not hard to see why the "post-political" has proven such an attractive concept for planning scholars, capturing as it does how the terms of debate have been narrowed, shutting out anything that might challenge the neoliberal settlement around "light touch" regulation and market-led planning (see Metzger (2018) for a sympathetically critical review on the post-political in planning). Sustaining this reductive and largely negative view of the role of planning also involves closing down other possibilities.

From my perspective, however, Walton's analysis of how the implementation of the 2006 Planning Etc. Scotland Act has limited scope for effective democratic scrutiny of what goes into development plans is not just another example of post-political planning. It also has considerable relevance for the work of groups like PD at the moment, laying down a challenge for thinking and acting in and against the contemporary conjuncture.

In this regard, one of the instructive lessons to come from the paper concerns how seemingly technical alterations to administrative processes can play a more significant role than even the decision-makers who sign them off intend. Indeed, the empirical evidence in the paper suggests that Members of the Scottish Parliament (MSP) did not realise they were agreeing to substantially limit the role and remit of plan inquiries/examinations. The loss of this forum for scrutinising development plans has reduced a potential source of friction, enabling the allocation of large areas of land for new residential settlements in Aberdeenshire. The dominant logic says this will smooth the path towards the market-led delivery of projected housing need. But at what cost?

Many scholars, Walton included, point towards what is variously displaced, repressed, undermined, or otherwise lost in the service of a post-political settlement. One of the other tenets of the postpolitical is the threat that what has been repressed may return, sometimes with a vengeance. The emergence of various more and less authoritarian populisms in recent years is, of course, the paradigmatic example of this. Trumpism, Brexit or the Five Star Movement in Italy all seem to be marked by the return, in disfigured form, of the repressed resentments of those shut out from the benefits of neoliberal capitalism. The politics of planning takes place in a less dramatic register but it is worth considering how planning's post-political settlement might come under pressure from the 
return of its own repressed energies. In doing so we might even come to see possibilities for reimagining planning and resources for making alternatives possible.

The current planning reform process in Scotland, for example, has begun to open up questions about some core aspects of the dominant logic. Prominent here has been a growing questioning of whether getting planning out of the way is actually a good way of "delivering" housing. Communities, like those the article focuses on in Aberdeenshire, are asking searching questions about the quality of new development, its affordability and the failure to resource infrastructure adequately. Others meanwhile are asking whether the large speculative house-building firms that dominate the market are equipped to produce the quantity of new homes that projections suggest are needed; particularly in so far as their business models are premised on profiting from land rather than actually building on it. The possibility of funding more proactive public planning by better capturing increases in land values is therefore back on the agenda and suggests a degree of openness to public intervention 'making the weather' and seeking to actively shape markets (e.g. Lord \& O'Brien 2017).

The voices of affected communities have also begun to be heard and, as Walton suggests, they have made very clear their sense of frustration and mistrust at a system that does not (or cannot) listen or take their concerns seriously. Tokenistic forms of public engagement have long been used to depoliticize planning processes and have been identified as a central facet of post-political planning. If the answer to nearly any question about development is known before it is even asked, the scope for meaningful engagement is inevitably limited. The longer-term, cumulative impacts of such tokenism on the legitimacy of planning and development may, however, be significant.

Much of this debate is currently crystalizing around the issue of appeal rights ${ }^{2}$. At present, applicants for development permits have the right to appeal against refusals of consent but there is no parallel right for communities to appeal against approvals, however controversial or questionable. This historical anomaly provides a clear focus for discontent about the unequal balance of power within the planning system in Scotland. PD have therefore been campaigning for the introduction of an "equal right of appeal" that would involve restricting the existing rights of applicants and extending them to affected communities.

Whilst not an issue that opens up the kind of fundamental fault-lines in society that might excite theorists of radical democracy, the issue is nonetheless a polarizing one. The Scottish Government, backed by a cosy corporatist alliance of professional and developer interests, have made their position very clear; seeking to close down debate, largely on the basis that such changes would work against the dominant logic of streamlining planning. There are MSPs from across the political spectrum, however, who are more sympathetic, often because they regularly hear from disgruntled constituents about imbalances of power in the planning system. As a result, PD are hopeful that the issue will not be dismissed this time, at least not without a bit of a stooshie ${ }^{3}$. Hence my train journey.

Through his focus on development plan inquiries/examinations, Walton's paper points to another significant aspect of the planning process in Scotland that has been quietly depoliticized. Unlike appeal rights, it is not an issue that is being much discussed at the moment. As such, it is a useful illustration of the multitude of ways in which the dominant logic of neoliberal planning has worked its way deep into the fabric of law and policy. This makes influencing planning reform in and against the dominant logic all the more daunting whilst also highlighting that it does remain worth bothering with. Any such work needs to operate simultaneously on at least two levels; engaging the battle of ideas over the proper definition and purposes of planning at a broad level whilst remaining attentive to the multiple fronts and more forensic levels of detail where the devil often lurks. I'm grateful for the reminder of how far there still is to travel.

\section{Notes}

${ }^{1}$ See http://www.planningdemocracy.org.uk/ or Inch (2015) where I discuss some of this work in a more academic frame.

${ }^{2}$ An issue that was also considered but ultimately rejected in the run up to the 2006 Act.

${ }^{3} \mathrm{~A}$ Scots word meaning a row or argument. 


\section{Acknowledgements}

This response was supported by a grant from FCT in Portugal (grant number SFRH/BPD/110582/2015).

\section{References}

Gunder, M. (2016) Planning's "failure" to ensure efficient market delivery: a Lacanian deconstruction of this neoliberal scapegoating fantasy. European Planning Studies 24(1) 21-38. https://doi.org/10.1080/09654313.2015.1067291

Inch, A. (2015) Ordinary citizens and the political cultures of planning: in search of the subject of a new democratic ethos. Planning Theory 14(4) 404-424. https://doi.org/10.1177/1473095214536172 Lord, A. \& O'Brien, P. (2017) What price planning? Reimagining planning as "market maker". Planning Theory \& Practice 18(2) 217-232. https://doi.org/10.1080/14649357.2017.1286369

Metzger, J. (2018) 'Postpolitics and planning'. In Gunder, M., Madanipour, A. \& Watson, V. (eds.) The Routledge Handbook of Planning Theory, 180-193. Routledge, Abingdon.

Walton, W. (2018) Deregulated free-for-all planning, new settlements and the spectre of abandoned building sites in Scotland's crisis-hit oil economy. Fennia 196(1) 58-76.

https://doi.org/10.11143/fennia.65626 